\title{
Microwave Preparation and Spectroscopic Investigation of Binuclear Schiff Base Metal Complexes Derived from 2,6-Diaminopyridine with Salicylaldehyde
}

\author{
Hasan A. Mohammed*, Nihad Ismeal Taha \\ Department of Chemistry, College of Science, University of Kirkuk, Kirkuk, Iraqi \\ Email: *Hassanahmed88@yahoo.com
}

How to cite this paper: Mohammed, H.A. and Taha, N.I. (2017) Microwave Preparation and Spectroscopic Investigation of Binuclear Schiff Base Metal Complexes Derived from 2,6-Diaminopyridine with Salicylaldehyde. International Journal of Organic Chemistry, 7, 412-419.

https://doi.org/10.4236/ijoc.2017.74033

Received: November 6, 2017

Accepted: December 22, 2017

Published: December 25, 2017

Copyright $\odot 2017$ by authors and Scientific Research Publishing Inc. This work is licensed under the Creative Commons Attribution International License (CC BY 4.0).

http://creativecommons.org/licenses/by/4.0/

\begin{abstract}
The binuclear Schiff base complexes prepared by condensation 2,6-diaminopyridine and salicylaldehyde (LH) by using microwave and adding metal salts to ligand by same ratio. The Schiff base ligand was checked by infrared, electronic spectra and ${ }^{1} \mathrm{HNMR}$ spectroscopy and prepared complexes characterized by molar conductivity, infrared, electronic spectra and susceptibility measurements. The values of molar conductivities reveal that the complexes are non-electrolytes, from obtained data of electronic spectra and magnetic moment, an octahedral geometry was suggested, coordinated to the metal ions in a manner with $\mathrm{N}$ donor sites of imine groups, and oxygen of phenolic $\mathrm{OH}$ group.
\end{abstract}

\section{Keywords}

Schiff Base, Binuclear Metal, Complexes, 2,6-Diaminopyridine, Salicylaldehyde

\section{Introduction}

The reactions of aldehyde or ketone with primarily amine in which carbonyl group is replaced by imine group is called Schiff bases, are widely used in organic synthesis [1]. Schiff bases' importance increased due to a wide range of applications [2]: Exhibit antimicrobial activity, fungicidal activity [3], pharmacological applications [4]. Salicylaldehyde is an important precursor to a variety of chelating agents [5]. Schiff bases of salicylaldehyde are well known as the polydentate ligands, coordinating as a deprotonated or neutral forms. Schiff bases 
used as a ligand in coordination chemistry because its donor ability that deals with Schiff bases and their metal complexes due to synthetic flexibility and sensitivity toward a variety of metal atom and there are many studies [6] which prove this situation [7] [8]. Recently, synthesized $\mathrm{Cu}(\mathrm{II}), \mathrm{Ni}(\mathrm{II})$ and $\mathrm{Co}(\mathrm{II})$ complexes show the current interest of researchers in the field of coordination chemistry of these metal ions [9]. Microwave is one of the modern green synthetic methodologies for Schiff bases [10] [11]. Many features of microwave approach are shorter reaction times, simple reaction conditions and enhancements in yields reactions under solvent free or less solvent conditions are attractive offering reduced pollution. In this paper, we prepare ligand (LH) (2,2'-((1E,1'E)-(pyridine-2,6-diylbis(azanylylidene)) bis (methanylylidene))diphenol) resulting from the condensation of salicylaldehyde with primary amines 2,6-diaminopyridine with some binuclear transition metals that the general formula $\left[\mathrm{M}_{2}(\mathrm{LH})_{2} \mathrm{Cl}_{4}\right]$.

\section{Experimental}

\subsection{Materials and Methods}

Higher grade reagents and solvents were commercially available (Fluka A.G., Merck, BDH) and used as received. Infrared spectra were recorded on a Nicolet 100 FTIR spectrophotometer in the $400-4000 \mathrm{~cm}^{-1}$ range using $\mathrm{KBr}$ discs. NMR spectroscopy recorded by Av 300 instrument. Conductivity measurements were carried out on $10^{-3} \mathrm{M}$ solution of the complexes in DMF using conductivity meter Jenway PCM3 at an ambient temperature. The electronic spectra were recorded on a PgT92+ UV-visible spectrophotometer for $10^{-3} \mathrm{M}$ solutions of complexes in DMF as solvent at $25^{\circ} \mathrm{C}$ using $1 \mathrm{~cm}$ quartz cell. Melting points were recorded on an Electrothermal 9300 apparatus. The magnetic susceptibility measurements were carried out at $25^{\circ} \mathrm{C}$ on the solids by Gouy's method using Sherwood Scientific instrument.

\subsection{Syntheses of the LIGAND \\ (2,2'-((1E,1'E)-(pyridine-2,6-Diylbis(Azanylylidene)) Bis(Methanylylidene))Diphenol) (LH)}

To a mixture of 2,6-diaminopyridine $(0.109 \mathrm{~g}, 0.001 \mathrm{~mol})$ and 2-hydroxybenzaldehyde $(0.2442 \mathrm{~g}, 0.002 \mathrm{~mol})$ add drop of glacial acetic acid were placed in the microwave oven and irradiated at $400 \mathrm{~W}$ for $1 \mathrm{~min}$. Then left to cool to room temperature. The solid so formed was filtered and recrystallized from ethanol.

\subsection{Synthesis of the Complexes $\left[\mathrm{M}_{2}(\mathrm{LH})_{2} \mathrm{Cl}_{2}\right] \mathrm{M}=\mathrm{Co}(\mathrm{II}), \mathrm{Ni}(\mathrm{II})$, $\mathrm{Cu}(\mathrm{II}), \mathrm{Zn}(\mathrm{II}), \mathrm{Cd}(\mathrm{II})$}

To an ethanoic solution of (LH) $(0.317 \mathrm{~g}, 0.001 \mathrm{~mol})$ was added dropwise to each ethanoic solution of $\mathrm{CoCl}_{2} \cdot 6 \mathrm{H}_{2} \mathrm{O}(2.30 \mathrm{~g}, 0.001 \mathrm{~mol}), \mathrm{NiCl}_{2} \cdot 6 \mathrm{H}_{2} \mathrm{O}(2.36 \mathrm{~g}, 0.001$ $\mathrm{mol}), \mathrm{CuSO}_{4}(0.167 \mathrm{~g}, 0.001 \mathrm{~mol}), \mathrm{ZnCl}_{2}(0.136 \mathrm{~g}, 0.001 \mathrm{~mol})$ and $\mathrm{CdCl}_{2}(0.183$, $0.001 \mathrm{~mol}$ ) with a stirring at a room temperature the precipitate formed was filtered off, washed with $10 \mathrm{ml}$ of water and dried under vacuum. 


\section{Results and Discussion}

The ligand was prepared by condensation of primary amine and aldehyde under microwave irradiated the complexes were prepared by direct addition of the ethanoic solution of the metals salts (Scheme 1).

The physical properties and analytical data for ligand and complexes are given in Table 1. The values of molar conductivities of the complexes in DMF (12 - 26 $\left.\mathrm{ohm}^{-1} \cdot \mathrm{cm}^{2} \cdot \mathrm{mol}^{-1}\right)$ indicate that all the prepared complexes are non-electrolytes [12]

Table 1. Analytical and some physical properties of the ligand and prepared complexes.

\begin{tabular}{cccccc}
\hline Comp. no. & Chemical formula & Color & $\mathrm{m} \cdot \mathrm{p}{ }^{\circ} \mathrm{C}$ & $\Lambda \mathrm{ohm}^{-1} \cdot \mathrm{cm}^{2} \cdot \mathrm{mol}^{-1}$ & Yield \% \\
\hline 1 & $\mathrm{LH}$ & Light yellow & 210 & - & 85 \\
2 & {$\left[\mathrm{Co}_{2}(\mathrm{LH})_{2} \mathrm{Cl}_{4}\right]$} & Dark green & $240 \mathrm{Dec}$ & 22 & 80 \\
3 & {$\left[\mathrm{Ni}_{2}(\mathrm{LH})_{2} \mathrm{Cl}_{4}\right]$} & Light green & $245 \mathrm{Dec}$ & 23 & 76 \\
4 & {$\left[\mathrm{Cu}_{2}(\mathrm{LH})_{2} \mathrm{Cl}_{4}\right]$} & Black & $285 \mathrm{Dec}$ & 26 & 90 \\
5 & {$\left[\mathrm{Zn}_{2}(\mathrm{LH})_{2} \mathrm{Cl}_{4}\right]$} & Light yellow & $221 \mathrm{Dec}$ & 18 & 82 \\
6 & {$\left[\mathrm{Cd}_{2}(\mathrm{LH})_{2} \mathrm{Cl}_{4}\right]$} & Light yellow & $235 \mathrm{Dec}$ & 12 & 78 \\
\hline
\end{tabular}

Dec $=$ decompose<smiles>Nc1cccc(N)n1</smiles>

pyridine-2,6-diamine 2-hydroxybenzaldehyde<smiles>Cc1cccc(/N=C/c2ccccc2O)n1</smiles><smiles>Oc1ccccc1/C=N/c1cccc(/N=C/c2ccccc2O)n1</smiles>

2,2'-((1E,1'E)-(pyridine-2,6diylbis(azanylylidene))bis(methanylylidene))diph enol

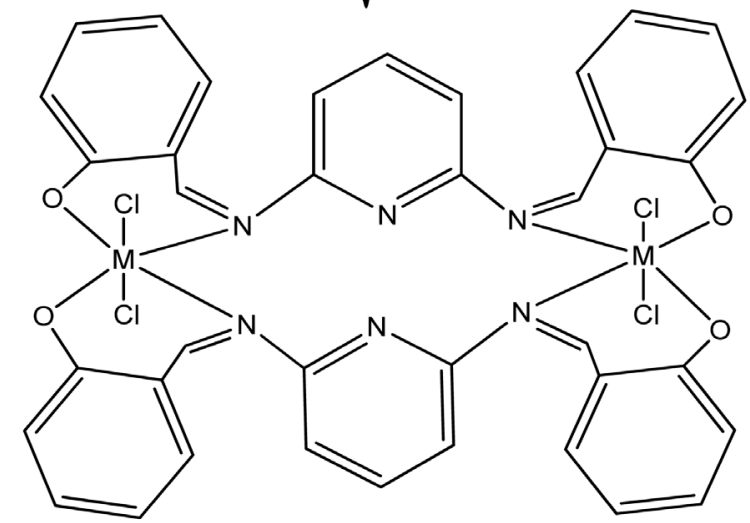

Scheme 1. Preparation of ligand and complexes. $M=C o, N i$, when $x=6 ; M=C u, Z n, C d$, when $x=0$. 


\subsection{Infra-Red Spectroscopy}

The most important of infrared frequencies of Schiff base and its $\mathrm{Co}(\mathrm{II}), \mathrm{Ni}(\mathrm{II})$, $\mathrm{Cu}(\mathrm{II}), \mathrm{Zn}(\mathrm{II}), \mathrm{Cd}(\mathrm{II})$ complexes are recorded in Table 2. The spectrum of ligand showed the absence of $\mathrm{C}=\mathrm{O}$ absorption band at $1850-1650 \mathrm{~cm}^{-1}$. And appearance of a new band at $(1601) \mathrm{cm}^{-1}$ due to azomethine spectra, suggest the formation of ligand [13] [14]. The ligand spectra show a broad band at 3375 $\mathrm{cm}^{-1}$ due to stretching vibration of $v(\mathrm{O}-\mathrm{H})$, as well as the $\mathrm{C}-\mathrm{N}$ band at 1454 $\mathrm{cm}^{-1}$, the band at $1601 \mathrm{~cm}^{-1}$ assign to $v(\mathrm{C}=\mathrm{N})$, and the $v(\mathrm{C}-\mathrm{O})$ band at 1277 $\mathrm{cm}^{-1}[15]$. The prepared complexes exhibited very comparable IR features, suggesting that they are of similar structure [16]. In the complexes the absorption band of stretching vibrations $v(\mathrm{O}-\mathrm{H})$ disappeared which is assigned to the complexes formation [17]. The complexes shown absorption bands (1608 - 1613) $\mathrm{cm}^{-1}$ due to $v(\mathrm{C}=\mathrm{N})$ shifted to higher frequency compared with ligand [18] [19]. And absorption band of $v(\mathrm{C}-\mathrm{N})$ shows a shifted to lower frequency assign to coordination [7]. The bands in the region of $(586-421) \mathrm{cm}^{-1}$ confirm the nature of the metal-ligand bonding [20].

\section{2. ${ }^{1}$ HNMR Spectroscopy}

The ${ }^{1} \mathrm{HNMR}$ spectrum of ligand (LH), Figure 1 in DMSO- $\mathrm{d}^{6}$ solvent shows a signal at $(\delta=10.27 \mathrm{ppm}$ ) equivalent to two protons assigned to $(\mathrm{O}-\mathrm{H})$ group of carbon [21]. Two protons of $(\mathrm{N}=\mathrm{C}-\mathrm{H})$ imine group appears as a signal at $(\delta=$ 9.31, $9.96 \mathrm{ppm}$ ). The multiplet signals at ( $\delta=6.11 \mathrm{ppm}),(6.68),(6.9),(7.0)$, (7.35), (7.48), (7.53), (7.95) ppm are due to aromatic hydrogen of carbon [22].

Table 2. FT-IR spectral data of ligand and complexes.

\begin{tabular}{ccccccc}
\hline Compound & $v(\mathrm{O}-\mathrm{H})$ & $v(\mathrm{C}-\mathrm{N})$ & $v(\mathrm{C}=\mathrm{N})$ & $v(\mathrm{C}-\mathrm{O})$ & $v(\mathrm{M}-\mathrm{N})$ & $v(\mathrm{M}-\mathrm{O})$ \\
\hline $\mathrm{LH}$ & 3375 & 1454 & 1601 & 1277 & & \\
{$\left[\mathrm{Co}_{2}(\mathrm{LH})_{2} \mathrm{Cl}_{4}\right]$} & - & 1456 & 1608 & 1225 & 568 & 443 \\
{$\left[\mathrm{Ni}_{2}(\mathrm{LH})_{2} \mathrm{Cl}_{4}\right]$} & - & 1457 & 1609 & 1228 & 586 & 427 \\
{$\left[\mathrm{Cu}_{2}(\mathrm{LH})_{2} \mathrm{Cl}_{4}\right]$} & - & 1456 & 1613 & 1231 & 512 & 432 \\
{$\left[\mathrm{Zn}_{2}(\mathrm{LH})_{2} \mathrm{Cl}_{4}\right]$} & - & 1454 & 1612 & 1234 & 534 & 422 \\
{$\left[\mathrm{Cd}_{2}(\mathrm{LH})_{2} \mathrm{Cl}_{4}\right]$} & - & 1458 & 1610 & 1227 & 572 & 451 \\
\hline
\end{tabular}

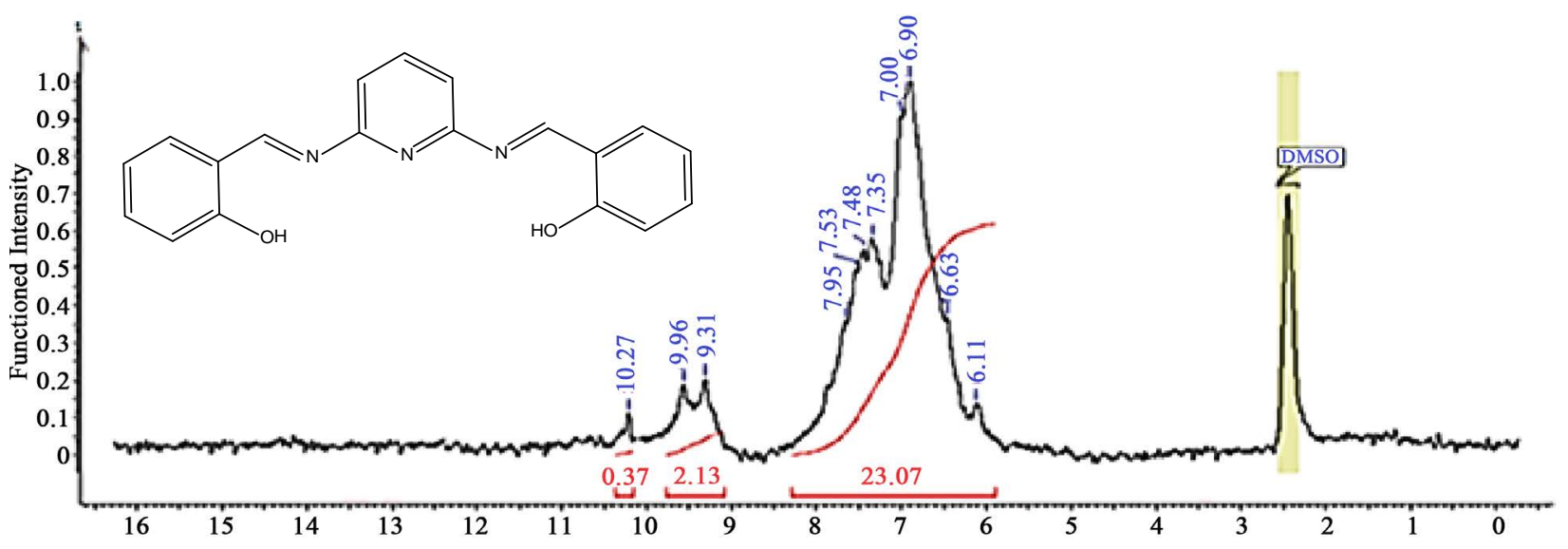

Figure $1 .{ }^{1} \mathrm{HNMR}$ spectrum of the ligand $(\mathrm{LH})$. 


\subsection{Electronic Spectra}

The electronic spectra of ligand appeared two band at $(26,455,35,971) \mathrm{cm}^{-1}$ is assigned to $\left(\mathrm{n} \rightarrow \pi^{*}\right)\left(\pi \rightarrow \pi^{*}\right)$ transition respectively [23]. The cobalt(II) complex displays bands at $\left(13661 \mathrm{~cm}^{-1}\right),\left(13,888 \mathrm{~cm}^{-1}\right)$ and $\left(26,881 \mathrm{~cm}^{-1}\right)$ referring to ${ }^{4} \mathrm{~T}_{1 g}(\mathrm{~F}) \rightarrow{ }^{4} \mathrm{~T}_{2 g}(\mathrm{~F}),{ }^{4} \mathrm{~T}_{1 g}(\mathrm{~F}) \rightarrow{ }^{4} \mathrm{~A}_{2 g}(\mathrm{~F}),{ }^{4} \mathrm{~T}_{1 \mathrm{~g}}(\mathrm{~F}) \rightarrow{ }^{4} \mathrm{~T}_{1 \mathrm{~g}}(\mathrm{P})$ respectively and other charge transfer bands at $\left(31,645 \mathrm{~cm}^{-1}\right)$ [24]. The nickel(II) complex displays bands at $\left(12,820 \mathrm{~cm}^{-1}\right),\left(14,025 \mathrm{~cm}^{-1}\right)$ and $\left(25,906 \mathrm{~cm}^{-1}\right)$ referring to $\left({ }^{3} \mathrm{~A}_{2 \mathrm{~g}}\right.$ $\left.(\mathrm{F}) \rightarrow{ }^{3} \mathrm{~T}_{2 \mathrm{~g}}(\mathrm{~F})\right),\left({ }^{3} \mathrm{~A}_{2 \mathrm{~g}}(\mathrm{~F}) \rightarrow{ }^{3} \mathrm{~T}_{1 \mathrm{~g}}(\mathrm{~F})\right),\left({ }^{3} \mathrm{~A}_{2 \mathrm{~g}}(\mathrm{~F}) \rightarrow{ }^{3} \mathrm{~T}_{1 \mathrm{~g}}(\mathrm{P})\right)$ respectively and other charge transfer bands at $\left(37313 \mathrm{~cm}^{-1}\right)$ [25]. The electronic spectrum of $\mathrm{Cu}$ (II) complex shows a band at $\left(12,106 \mathrm{~cm}^{-1}\right)$, referring to $\left({ }^{2} \mathrm{Eg} \rightarrow{ }^{2} \mathrm{~T}_{2} \mathrm{~g}\right)$ and anther charge transfer band at $\left(37,593 \mathrm{~cm}^{-1}\right)$. The electronic spectrum of $\mathrm{Zn}(\mathrm{II})$ and $\mathrm{Cd}(\mathrm{II})$ shows a bands at $\left(26,178-31,645 \mathrm{~cm}^{-1}\right)$, which is assigned to charge transfer as it's shown in the Table 3.

\subsection{Magnetic Properties}

The cobalt complex exhibit magnetic moment value of 4.80 B.M. this value is greater than spin only due to orbital contribution suggesting octahedral geometry [26]. The $\mathrm{Ni}$ (II) complex show magnetic moment value of 2.82 B.M. indicating an octahedral environment. The observed magnetic moment values for the $\mathrm{Cu}$ (II) complex are 1.84 suggesting a distorted octahedral geometry [27].

Table 3. Electronic spectral data of the complexes.

\begin{tabular}{|c|c|c|c|c|c|}
\hline Comp. no. & Chemical formula & Band position & Assignments & Geometry & $\mu_{\text {eff }}$ B.M \\
\hline \multirow{3}{*}{1} & \multirow{3}{*}{ LH } & 26,455 & $\mathrm{n} \rightarrow \pi^{*}$ & & \multirow{3}{*}{--} \\
\hline & & & & & \\
\hline & & 35,971 & $\pi \rightarrow \pi^{*}$ & & \\
\hline \multirow{4}{*}{2} & \multirow{4}{*}[\mathrm{Co}_{2}(\mathrm{LH})_{2}\mathrm{Cl}_{4}]{} & 13,661 & ${ }^{4} \mathrm{~T}_{1 \mathrm{~g}}(\mathrm{~F}) \rightarrow{ }^{4} \mathrm{~T}_{2 \mathrm{~g}}(\mathrm{~F})$ & \multirow{4}{*}{ octahedral } & \multirow{4}{*}{4.8} \\
\hline & & 13,888 & ${ }^{4} \mathrm{~T}_{1 \mathrm{~g}}(\mathrm{~F}) \rightarrow{ }^{4} \mathrm{~A}_{2 \mathrm{~g}}(\mathrm{~F})$ & & \\
\hline & & 26,881 & ${ }^{4} \mathrm{~T}_{1 \mathrm{~g}}(\mathrm{~F}) \rightarrow{ }^{4} \mathrm{~T}_{1 \mathrm{~g}}(\mathrm{P})$ & & \\
\hline & & 31,645 & Charge transfer & & \\
\hline \multirow{4}{*}{3} & \multirow{4}{*}[\mathrm{Ni}_{2}(\mathrm{LH})_{2}\mathrm{Cl}_{4}]{} & 12,820 & ${ }^{3} \mathrm{~A}_{2 \mathrm{~g}}(\mathrm{~F}) \rightarrow{ }^{3} \mathrm{~T}_{2 \mathrm{~g}}(\mathrm{~F})$ & \multirow{4}{*}{ octahedral } & \multirow{4}{*}{2.82} \\
\hline & & 14,025 & ${ }^{3} \mathrm{~A}_{2 \mathrm{~g}}(\mathrm{~F}) \rightarrow{ }^{3} \mathrm{~T}_{1 \mathrm{~g}}(\mathrm{~F})$ & & \\
\hline & & 25,906 & ${ }^{3} \mathrm{~A}_{2 \mathrm{~g}}(\mathrm{~F}) \rightarrow{ }^{3} \mathrm{~T}_{1 \mathrm{~g}}(\mathrm{p})$ & & \\
\hline & & 37,313 & Charge transfer & & \\
\hline \multirow[b]{2}{*}{4} & \multirow{2}{*}[\mathrm{Cu}_{2}(\mathrm{LH})_{2}\mathrm{Cl}_{4}]{} & 12,106 & ${ }^{2} \mathrm{Eg} \rightarrow{ }^{2} \mathrm{~T}_{2} \mathrm{~g}$ & \multirow{2}{*}{ octahedral } & \multirow{2}{*}{1.84} \\
\hline & & 37,593 & Charge transfer & & \\
\hline \multirow[b]{2}{*}{5} & \multirow[b]{2}{*}[\mathrm{Zn}_{2}(\mathrm{LH})_{2}\mathrm{Cl}_{4}]{} & 26,315 & Charge transfer & \multirow[b]{2}{*}{ octahedral } & \multirow[b]{2}{*}{ dia } \\
\hline & & 28,735 & Charge transfer & & \\
\hline \multirow[b]{2}{*}{6} & \multirow[b]{2}{*}[\mathrm{Cd}_{2}(\mathrm{LH})_{2}\mathrm{Cl}_{4}]{} & 26,178 & Charge transfer & \multirow[b]{2}{*}{ octahedral } & \multirow[b]{2}{*}{ dia } \\
\hline & & & & & \\
\hline
\end{tabular}




\section{Conclusion}

The synthesized Schiff base ligand and its binuclear metal complexes were characterized by various techniques. The data obtained from various studies are in good agreement with proposed structure of the Schiff base ligand and its metal complexes. From the above discussion, we suggested that the structure of complexes is octahedral geometry except $\mathrm{Cu}(\mathrm{II})$ complex is distorted octahedral.

\section{References}

[1] Usharani, M., Akdla, E., Ashokan R. and Rajavi, R. (2013) Pharmacological Properties of Schiff Base Metal Complexes Derived from Substituted Pyridine and Aromatic Amine-A Review. International Journal of Pharmaceutical Sciences and Health Care, 5, 1-11.

[2] Al Zoubi, W. (2013) Biological Activities of Schiff Bases and Their Complexes: A Review of Recent Works. International Journal of Organic Chemistry, 3, 73-95. https://doi.org/10.4236/ijoc.2013.33A008

[3] Naser, A.W. and Majeed, A.M. (2015) Synthesis of Some New Sulfonamide Derivatives Based on 1,3,4-oxadiazole. Journal of Chemical and Pharmaceutical Research, 7, 300-306.

[4] Mohammed, M.Y., Abd, A.N. and Ali, A.S. (2017) Synthesis and Characterization Some of Metals(II) Complexes with Mixed Ligands of Saccharinate and Isatin Schiff Base. Tikrit Journal of Pure Science, 22, 56-64.

[5] Aliyu, H.N. and Sani, U. (2012) Synthesis, Characterization and Biological Activity of Manganese (II), Iron(II), Cobalt(II), Nickel(II) and Copper(II) Schiff Base Complexes against Multidrug Resistant Bacterial and Fungal Pathogens. International Research Journal of Pharmacy and Pharmacology, 2, 40-44.

[6] Pallikkavil, R. and Ummathur, M.B. (2012) Schiff Bases of Terephthalaldehyde with 2-Aminophenol and 2-Aminothiophenol and Their Metal Complexes. Archives of Applied Science Research, 4, 2223-2227.

[7] Mishra, A.P. and Jain, R.K. (2010) Microwave Synthesis, Spectroscopic, Thermal and Biological Significance of Some Transition Metal Complexes Containing Heterocyclic Ligands. Journal of Chemical and Pharmaceutical Research, 2, 51-61.

[8] Maher, K.A. and Mohammed, S.R. (2015) Metal Complexes of Schiff Base Derived from Salicylaldehyde-A Review. International Journal of Current Research and Review, 7, 6-16.

[9] Srivastava, A.N., Singh, N.P.A.L. and Shriwastaw, C.K. (2014) Synthesis and Characterization of Bioactive Binuclear Transition Metal Complexes of a Schiff Base Ligand Derived from 4-Amino-1H-Pyrimidin-2-One, Diacetyl and Glycine. Journal of the Serbian Chemical Society, 79, 421-433. https://doi.org/10.2298/JSC130123148S

[10] Al-Zayd, K.M. (2009) Microwave and Ultrasound Promoted Synthesis of Substituted New Arylhydrazono Pyridinones. Arabian Journal of Chemistry, 2, 89-94.

[11] Kapadnis, K.H., et al. (2016) Four Synthesis Methods of Schiff Base Ligands and Preparation of Their Metal Complex with Ir and Antimicrobial Investigation. World Journal of Pharmacy and Pharmaceutical Sciences, 5, 1055-1063.

[12] Priya, B. and Lakshmi, S. (2014) Synthesis, Spectral and Antimicrobial Investigation of some Ternary Schiff Base Transition Metal Complexes. International Journal of ChemTech Research, 6, 87-94. 
[13] Shakir, M. and Abbasi, A. (2015) Synthesis and Spectral Characterization of Hydrazone Schiff Base Ligand, L Derived from Condensation of Terephthalaldehyde and 2-Furoic Acid Hydrazide and Its Binuclear Complexes with $\mathrm{Co}(\mathrm{II}), \mathrm{Ni}(\mathrm{II})$, $\mathrm{Cu}(\mathrm{II})$ and $\mathrm{Zn}(\mathrm{II})$ : Compa. Journal of Chemical and Pharmaceutical Research, 7, 375-382.

[14] Ali, F. (2014) Synthesis and Characterization Antibacterial Activity of Novel Ligand-2, 6-Diaminopyridine-2-Acetyl-5-Chlorothiophene and Its Metal(II) Complexes. World Journal of Pharmaceutical Research, 3, 932-940.

[15] Abdlseed, F.A. (2009) Preparation and Spectroscopic Investigation of a Schiff Base Metal Complexes. International Journal of Pharm Tech Research, 1, 1097-1103.

[16] Salih, İ., Hamdi, T., Murat, S. and İbrahim, T. (2008) Synthesis, Structural Characterization of New Macrocyclic Schiff Base Derived from 1,6-bis(2-formylphenyl)hexane and 2,6-diaminopyridine and Its Metal Complexes. Indian Journal of Chemistry, 47, 560-564.

[17] Ocek, N.K., Ocek, S.K. and Kormali, F. (2007) Mono-, Di- and Tri-Nuclear Copper (II) Complexes of a Schiff Base Ligand, 2-\{(E)-[(6-\{[(1E)-(2-hydroxyphenyl) methylene]amino\}pyridin-2-yl)imino]-methyl $\}$ phenol. Turkish Journal of Chemistry, 31, 271-277.

[18] Etorki, A., Ben-saber, S. and Maihub, A. (2013) Metal Ions Uptake using Schiff Bases Derived from Salicylaldehyde and Appropriate Amino Compounds. Journal of Chemistry and Chemical Engineering, 7, 193-199.

[19] El-Sonbati, A.Z. and El-Bindary, A.A. (2000) Stereochemistry of New Nitrogen Containing Aldehydes. V. Novel Synthesis and Spectroscopic Studies of Some Quinoline Schiff Bases Complexes. Polish Journal of Chemistry, 74, 621-630.

[20] Kumar, S.P., Suresh, R., Giribabu, K., Manigandan, R., Munusamy, S. and Muthamizh, S. (2015) Synthesis, Characterization of Nickel Schiff Base Complex and Its Electrocatalytic Sensing Nature for $\mathrm{Hg}+2$. International Journal of Innovative Research in Science Engineering and Technology, 4, 123-130.

[21] Mahmoud, M.J., Numan, A.T. and Al-Obaidi, O.B.M.S. (2013) Synthetic and Characterization of Some New Schiff Bases Complexes. Journal of Al-Nahrain University Science, 16, 82-63.

[22] Usharani, M., Akila, E., Ramachandran, S., Velraj, G. and Rajavel, R. (2013) Synthesis, Composition, Geometry and Antibacterial Assay of Binuclear Schiff Base Metal Complexes Derived from Benzene-1,4-Dicarbaldehyde, 2-Hydroxy-Benzaldehyde and Pyridine-2,6-Diamine. International Journal of Pharmacy and Pharmaceutical Sciences, 5, 639-647.

[23] Al-obaidi, O.H. (2012) Synthesis, Characterization and Theoretical Treatment of Sandwich Schiff Base Complexes Derived from Urea and Thiourea with Some Transition Metals and Study of Its Biological Activity. Journal of Applied Chemistry, 1, 352-359.

[24] Al-jeboori, F.H.A., Hammud, K.K. and Al-jeboori, M.J. (2014) Synthesis and Characterization of New Acyclic Octadentate Ligand and Its Complexes. International Journal of Research in Pharmacy and Chemistry, 4, 154-167.

[25] Usharani, M., Akila, E. and Rajavel, R. (2013) Dinuclear Cu(II), Co(II), Ni(II) and $\mathrm{Mn}$ (II) Complexes Framework Based on 1-(2-hydroxyphenyl) Ethanone Ligand: Synthesis, Structural Investigation and Biological Properties. International Journal of Pharmaceutical Sciences Review and Research, 21, 274-280.

[26] Thakor, Y.J., Patel, S.G. and Patel, K.N. (2011) Synthesis, Characterization and Biocidal Studies of $\mathrm{Ni}(\mathrm{II}), \mathrm{Cu}(\mathrm{II})$, Dentate and Neutral Bi Dentate Schiff Base. Der 
Chemica Sinica, 2, 43-51.

[27] Usharani, M., Akila, E., Jayaseelan, P. and Rajavel, R. (2013) Structural Elucidation of Newly Synthesized Potentially Active Binuclear Schiff Base Cu(II), Ni(II), Co(II) and $\mathrm{Mn}(\mathrm{II})$ Complexes using Physicochemical Methods. International Journal of Scientific and Engineering Research, 4, 1055-1064. 